\title{
The link between idiopathic intracranial hypertension, fibromyalgia, and chronic fatigue syndrome: exploration of a shared pathophysiology
}

This article was published in the following Dove Press journal: Journal of Pain Research

\author{
Mieke Hulens' \\ Ricky Rasschaert ${ }^{2}$ \\ Greet Vansant ${ }^{3}$ \\ Ingeborg Stalmans ${ }^{4,5}$ \\ Frans Bruyninckx ${ }^{6}$ \\ Wim Dankaerts' \\ 'Department of Rehabilitation \\ Sciences, Faculty of Kinesiology \\ and Rehabilitation Sciences, \\ Musculoskeletal Rehabilitation \\ Research Unit, University of Leuven, \\ Leuven, Belgium; ${ }^{2}$ Department of \\ Neurosurgery, Sint-Jozefziekenhuis, \\ Bornem, Belgium; ${ }^{3}$ Department of \\ Social and Primary Health Care, \\ Public Health Nutrition, University \\ of Leuven, Leuven, Belgium; \\ ${ }^{4}$ Department of Neurosciences, \\ Ophthalmology Research Group, \\ University of Leuven KU Leuven, \\ Leuven, Belgium; ${ }^{5}$ Department of \\ Ophthalmology, University Hospitals \\ UZ Leuven, Leuven, Belgium; ${ }^{6}$ Clinical \\ Electromyography Laboratory, \\ Department of Academic Consultants, \\ Faculty of Medicine, University \\ Hospitals UZ Leuven, Leuven, Belgium
}

Correspondence: Mieke Hulens Department of Rehabilitation Sciences, Faculty of Kinesiology and Rehabilitation Sciences, Musculoskeletal Rehabilitation Research Unit, University of Leuven, Overwegstraat 14, 305I Sint-Joris-Weert, Leuven, Belgium

Tel +32478338003

Fax +32 I6 470559

Email miekehulens@skynet.be
Purpose: Idiopathic intracranial hypertension (IICH) is a condition characterized by raised intracranial pressure (ICP), and its diagnosis is established when the opening pressure measured during a lumbar puncture is elevated $>20 \mathrm{~cm} \mathrm{H}_{2} \mathrm{O}$ in nonobese patients or $>25 \mathrm{~cm} \mathrm{H}_{2} \mathrm{O}$ in obese patients. Papilledema is caused by forced filling of the optic nerve sheath with cerebrospinal fluid (CSF). Other common but underappreciated symptoms of IICH are neck pain, back pain, and radicular pain in the arms and legs resulting from associated increased spinal pressure and forced filling of the spinal nerves with CSF. Widespread pain and also several other characteristics of IICH share notable similarities with characteristics of fibromyalgia (FM) and chronic fatigue syndrome (CFS), two overlapping chronic pain conditions. The aim of this review was to compare literature data regarding the characteristics of IICH, FM, and CFS and to link the shared data to an apparent underlying physiopathology, that is, increased ICP.

Methods: Data in the literature regarding these three conditions were compared and linked to the hypothesis of the shared underlying physiopathology of increased cerebrospinal pressure.

Results: The shared characteristics of IICH, FM, and CFS that can be caused by increased ICP include headaches, fatigue, cognitive impairment, loss of gray matter, involvement of cranial nerves, and overload of the lymphatic olfactory pathway. Increased pressure in the spinal canal and in peripheral nerve root sheaths causes widespread pain, weakness in the arms and legs, walking difficulties (ataxia), and bladder, bowel, and sphincter symptoms. Additionally, IICH, FM, and CFS are frequently associated with sympathetic overactivity symptoms and obesity. These conditions share a strong female predominance and are frequently associated with EhlersDanlos syndrome.

Conclusion: IICH, FM, and CFS share a large variety of symptoms that might all be explained by the same pathophysiology of increased cerebrospinal pressure.

Keywords: chronic pain, fatigue, headache, Ehlers-Danlos, sympathetic activity, lymphatic olfactory pathway, small fiber neuropathy, Ménière's disease, Tarlov cysts

\section{Plain language summary}

The pathological mechanisms that cause both fibromyalgia (FM) and chronic fatigue syndrome (CFS) are incompletely understood. FM and CFS share very similar symptoms with idiopathic intracranial hypertension (IICH), a condition characterized by an increase in intracranial pressure (ICP) due to an unknown cause. The authors reviewed the literature to explore these common symptoms and to link them to the hypothesis that increased intracranial and spinal fluid pressure is the possible mechanism that initiates the multitude of symptoms in these 
conditions. The symptoms include neck pain, back pain, pain in arms and legs, numbness/tingling, headaches, fatigue, cognitive impairment, gradual loss of gray matter, in addition to symptoms involving cranial nerves, overload of the lymphatic system in the nasal mucosa and disturbance of the autonomic nervous system. Other shared characteristics include higher frequency in females and family members, and an association with obesity and Ehlers Danlos syndrome (a connective tissue disorder).

These findings are relevant as they provide an alternative hypothesis concerning the pathological mechanisms in FM and CFS.

\section{Introduction}

IICH is a condition characterized by elevated ICP of unknown etiology. Patients may present with headache, papilledema, and visual disturbances. The diagnosis is established when the opening pressure (OP) measured during a lumbar puncture is elevated $>20 \mathrm{~cm} \mathrm{H} \mathrm{H}_{2} \mathrm{O}$ in nonobese patients and $>25 \mathrm{~cm}$ $\mathrm{H}_{2} \mathrm{O}$ in obese patients. ${ }^{100}$

Recently, these cutoff values used to define IICH have been debated. ICP might rather be a continuum with no clear cutoff value. Additionally, headache and/or papilledema may be absent even if the ICP is above these cutoff values. As IICH and CFS share similar symptoms such as fatigue and headache, Higgins et al hypothesized that the milder forms of IICH may present as CFS. ${ }^{41}$

Common but underappreciated symptoms of $\mathrm{IICH}$ are neck pain, back pain, and radicular pain radiating to the arms and legs. These associated symptoms are due to the forced filling of the nerve roots with cerebrospinal fluid (CSF), irritating or compressing the nerve root fibers inside. ${ }^{10,38,43,53,67,72,88,101}$ Therefore, it is likely that milder forms of elevated ICP may also present as FM or unexplained pain. Indeed, FM has sensory symptoms and signs comparable to those of peripheral neuropathy. ${ }^{16,61,71,80,93,102}$ Moreover, electrophysiologic abnormalities have been detected in the limbs of patients with FM. ${ }^{15,97}$

This hypothesis may also provide an explanation for several overlapping chronic pain conditions.

While IICH is characterized by a significant increase in cerebrospinal pressure (CSP), FM and CFS may be the result of intermittent and/or mild chronic increased CSP.

The data in the literature regarding the signs and symptoms of these three conditions were compared and linked to the hypothesis of the shared underlying physiopathology of increased CSP.

Table 1 shows an overview of reported signs and symptoms for each condition associated with increased ICP; Table 2 presents signs and symptoms associated with increased spinal pressure. Figure 1 depicts an overview of the interactions of ICP with all the nerves presented in this paper, the olfactory lymphatic pathway, and the inner ear.

\section{Symptoms associated with increased ICP Headache}

Most patients with IICH present with headaches. Approximately one in three patients with IICH may already suffer from chronic headaches before diagnosis. ${ }^{101}$ Additionally, there is significant overlap between the headache types observed in patients with IICH and the headache types of primary headache disorders. ${ }^{59}$ When performing a lumbar puncture in patients with unresponsive migraine without papilledema, $86 \%$ display an $\mathrm{OP}>20 \mathrm{~cm} \mathrm{H}_{2} \mathrm{O}$. Evacuation of CSF induces headache remission in $77 \% .{ }^{25}$ However, when the ICP is reduced in patients with IICH using a shunt, the different types of headaches may persist. Therefore, headache is a poor marker of disease activity. ${ }^{104}$

In patients with FM or CFS, different types of primary headaches such as migraine and tension headache are highly prevalent. 51,79

In patients with CFS suffering from headaches, a lumbar puncture revealed an $\mathrm{OP} \geq 20 \mathrm{~cm} \mathrm{H}_{2} \mathrm{O}$ in $40 \%$ of patients, and evacuation of CSF improved headaches, alertness, and/ or fatigue in $85 \%{ }^{41}$

\section{Fatigue}

Fatigue is the most pronounced symptom of IICH and one of the core symptoms of CFS and FM. Patients with CFS respond to spinal fluid evacuation the same way that patients with IICH do, that is, improvement of the headaches and fatigue. ${ }^{41}$

\section{Cognitive impairment}

Patients with IICH may suffer multidomain cognitive impairment and impaired processing speed, which does not improve after normalization of the ICP. ${ }^{103,105}$

It is well established that FM and CFS patients may experience mental fogginess. In patients with FM, the term "fibrofog" is used. Cognitive impairment is also measurable in these patients. ${ }^{17,56}$ Moreover, in both patients with FM and those with CFS, the most pronounced finding in cognitive testing is impaired processing speed. This finding may be a sign of premature aging, as it is also the most prominent abnormality in cognitive aging. ${ }^{22,56}$ 
Table I Overview of the reported signs and symptoms for each condition that may be caused by increased ICP

\begin{tabular}{|c|c|c|c|c|}
\hline $\begin{array}{l}\text { Affected } \\
\text { system }\end{array}$ & Signs and symptoms & $\mathrm{IICH}$ & FM & CFS \\
\hline Hypothesis & & $\begin{array}{l}\text { Exacerbation of chronically } \\
\text { increased CSP } \\
>20-25 \mathrm{~cm} \mathrm{H}_{2} \mathrm{O}\end{array}$ & $\begin{array}{l}\text { Chronic moderate } \\
\text { cerebrospinal hypertension } \\
\left(\mathrm{I} 2-2 \mathrm{O} \mathrm{cm} \mathrm{H}_{2} \mathrm{O}\right) \\
\text { predominantly affecting the } \\
\text { peripheral nervous system }\end{array}$ & $\begin{array}{l}\text { Chronic moderate } \\
\text { cerebrospinal hypertension } \\
\left(12-20 \mathrm{~cm} \mathrm{H}_{2} \mathrm{O}\right) \\
\text { predominantly affecting the } \\
\text { central nervous system }\end{array}$ \\
\hline \multirow{5}{*}{$\begin{array}{l}\text { Increased } \\
\text { cranial } \\
\text { pressure }\end{array}$} & Migraine & $\begin{array}{l}\text { 70.4\% of unresponsive migraine } \\
\text { patients have } \mathrm{IICH}^{25}\end{array}$ & $55.8 \%{ }^{99}$ & $84 \%^{79}$ \\
\hline & Headaches & $\begin{array}{l}\text { - } 84 \% \text { acute }^{101} \\
\text { - } 32 \% \text { chronic }^{104}\end{array}$ & $68 \%$ tension headaches ${ }^{51}$ & $81 \%$ tension headaches ${ }^{79}$ \\
\hline & Fatigue & Common $^{41}$ & Core symptom ${ }^{20}$ & Core symptom ${ }^{41}$ \\
\hline & Cognitive impairment & $\begin{array}{l}\text { - Deficits in processing speed } \\
\text { and reaction time }{ }^{105} \\
\text { - Persists after normalization of } \\
\text { ICP103 }\end{array}$ & Impaired processing speed ${ }^{56}$ & Impaired processing speed ${ }^{22}$ \\
\hline & Loss of gray matter & & $\begin{array}{l}\text { 3.3-fold greater age-associated } \\
\text { decrease in gray matter } \\
\text { volume }^{57}\end{array}$ & $\begin{array}{l}\text { Regional gray and white } \\
\text { matter volume reduction }\end{array}$ \\
\hline \multirow[t]{10}{*}{$\begin{array}{l}\text { Cranial nerve } \\
\text { involvement }\end{array}$} & Olfactory nerve & $\begin{array}{l}\text { - Decreased olfactory bulb } \\
\text { volume }^{91} \\
\text { - Impaired olfactory function } \\
\end{array}$ & $\begin{array}{l}\text { - Decreased olfactory bulb } \\
\text { volume }^{90} \\
\text { - Impaired olfactory function } \\
\end{array}$ & \\
\hline & $\begin{array}{l}\text { II } \\
\text { Optic nerve }\end{array}$ & $\begin{array}{l}\text { - Increased optic nerve sheath } \\
\text { diameter }{ }^{96} \\
\text { - Visual field constriction }{ }^{27} \\
\text { - Papilledema }\end{array}$ & $\begin{array}{l}\text { - Retinal nerve fiber } \\
\text { thinning } \\
\text { - Decreased perfusion of the } \\
\text { optic nerve } \\
\text { - } 10 \% \text { loss of peripheral } \\
\text { vision }^{102}\end{array}$ & \\
\hline & $\begin{array}{l}\text { III Oculomotor } \\
\text { IV Trochlear motor } \\
\text { VI Abducens }\end{array}$ & $\begin{array}{l}\text { - } 18 \% \text { double vision }{ }^{101} \\
\text { - Horizontal double vision }{ }^{59}\end{array}$ & $\begin{array}{l}\text { - Eye motility dysfunction }{ }^{87} \\
\text { - } 15 \% \text { double vision }{ }^{102}\end{array}$ & $\begin{array}{l}\text { Eye motility dysfunction }^{6} \\
\text { Binocular vision } \\
\text { dysfunction }^{37}\end{array}$ \\
\hline & $\begin{array}{l}\text { V Trigeminal nerve } \\
\text { Motor: muscles of } \\
\text { mastication } \\
\text { Sensory: face, cornea }\end{array}$ & $\begin{array}{l}\text { Electromyography-proven } \\
\text { trigeminal neuropathy }{ }^{4}\end{array}$ & $\begin{array}{l}\text { - } 71 \%-94 \% \text { masticatory pain }{ }^{68} \\
\text { - Lacrimal nerve: ocular pain } \\
\text { syndromes }{ }^{58} \\
\text { - Decreased corneal small } \\
\text { fiber density } \\
\end{array}$ & $\begin{array}{l}21 \%-32 \% \\
\text { temporomandibular } \\
\text { disorders }^{83}\end{array}$ \\
\hline & $\begin{array}{l}\text { VII } \\
\text { Facial nerve } \\
\text { Motor: facial muscles }\end{array}$ & - $5 \%$ with seventh nerve palsy ${ }^{101}$ & & \\
\hline & $\begin{array}{l}\text { VII Submandibular } \\
\text { salivary glands and } \\
\text { lacrimal glands }\end{array}$ & Sicca syndrome ${ }^{94}$ & $\begin{array}{l}\text { - }>49 \text { years of age: } 80 \% \text { dry } \\
\text { eye syndrome }{ }^{88} \\
\text { - } 71 \% \text { xerostomia }^{81}\end{array}$ & $82 \%$ Sicca syndrome ${ }^{89}$ \\
\hline & VIII & Ménière's disease ${ }^{21,78,95}$ & - $30 \%$ vertigo 102 & Vestibular dysfunction ${ }^{5,73}$ \\
\hline & Vestibulocochlear & Hearing loss $\mathrm{s}^{21,78,101}$ & $25 \%$ hearing loss ${ }^{49,102}$ & \\
\hline & $\begin{array}{l}\text { IX Glossopharyngeal } \\
X \text { Vagus laryngeal and } \\
\text { pharyngeal muscles }\end{array}$ & & $\begin{array}{l}\text { - } 42 \% \text { hoarseness }^{102} \\
\text { - } 37.3 \% \text { dysphagia }{ }^{81}\end{array}$ & \\
\hline & $X$ Vagus visceromotor & $\begin{array}{l}\text { Slower gastric emptying } \\
\text { associated with increased ICP } 66\end{array}$ & $\begin{array}{l}\text { - Belching, reflux, bloating, } \\
\text { sour taste, and vomiting }{ }^{74}\end{array}$ & - Slower gastric emptying ${ }^{12}$ \\
\hline $\begin{array}{l}\text { Olfactory } \\
\text { lymphatic } \\
\text { pathway }\end{array}$ & $\begin{array}{l}\text { Evacuation of CSF via } \\
\text { the lamina cribriformis } \\
\text { to the lymphatic vessels } \\
\text { of the nasal mucosa }\end{array}$ & $\begin{array}{l}\text { - Sinusitis } \\
\text { - Spontaneous CFS leak with } \\
\text { rhinorrhea }\end{array}$ & - $46 \%$ nonallergic rhinitis ${ }^{7}$ & $\begin{array}{l}\text { - Idiopathic nonallergic } \\
\text { rhinitis is highly prevalent } \\
\text { in } \mathrm{CFS}^{8}\end{array}$ \\
\hline
\end{tabular}

Notes: The percentages represent the proportion of patients displaying that sign or symptom, unless indicated otherwise.

Abbreviations: CFS, chronic fatigue syndrome; CSF, cerebrospinal fluid; CSP, cerebrospinal pressure; FM, fibromyalgia; ICP, intracranial pressure; IICH, idiopathic intracranial hypertension. 
Table 2 Overview of the reported signs and symptoms for each condition that may be caused by increased spinal pressure

\begin{tabular}{|c|c|c|c|c|}
\hline & Symptoms & $\mathrm{IICH}$ & FM & CFS \\
\hline $\begin{array}{l}\text { Increased spinal } \\
\text { pressure }\end{array}$ & Allodynia/radiculopathy & Radiculopathy 10,38,53,67,72,88,101 & $72 \%$ radiating pain ${ }^{55}$ & $\begin{array}{l}\text { Sharp, shooting, burning } \\
\text { pain }^{17}\end{array}$ \\
\hline \multirow[t]{4}{*}{$\begin{array}{l}\text { Cervical and } \\
\text { lumbar nerve } \\
\text { roots }\end{array}$} & $\begin{array}{l}\text { Paresthesia/numbness in } \\
\text { extremities }\end{array}$ & $\begin{array}{l}22 \% \text { distal extremity } \\
\text { paresthesia }^{88}\end{array}$ & $\begin{array}{l}\text { - } 19 \%-84 \% \text { numbness }^{55,102} \\
\text { - } 88 \% \text { stocking hypoesthesia }{ }^{16} \\
\text { - Objective sensory } \\
\text { abnormalities }\end{array}$ & $\begin{array}{l}69 \% \text { numbness/ } \\
\text { paresthesia }^{17,24}\end{array}$ \\
\hline & $\begin{array}{l}\text { Weakness in the arms } \\
\text { and legs }\end{array}$ & $69 \%$ objective weakness ${ }^{53}$ & $\begin{array}{l}\text { - } 58 \% \text { objective weakness } \\
\text { - } 13 \% \text { loss of muscle mass }{ }^{102}\end{array}$ & $\begin{array}{l}\text { Muscle weakness and } \\
\text { fasciculations }^{17}\end{array}$ \\
\hline & $\begin{array}{l}\text { Electrodiagnostic } \\
\text { abnormalities }\end{array}$ & $\begin{array}{l}62 \% \text { signs of demyelinating } \\
\text { polyneuropathy }{ }^{53}\end{array}$ & $\begin{array}{l}90 \% \text { signs of demyelinating and/ } \\
\text { or axonal polyneuropathy } 15,16,97\end{array}$ & \\
\hline & $\begin{array}{l}\text { Walking difficulties/ } \\
\text { ataxia }\end{array}$ & $12.2 \% \operatorname{ataxia}^{33}$ & $\begin{array}{l}\text { - } 26 \% \text { abnormal tandem test due } \\
\text { to ataxia } \\
\text { - } 63 \% \text { poor balance }{ }^{102}\end{array}$ & $\begin{array}{l}\text { Ataxia }^{17} \\
\text { Reduced gait automaticity }^{28}\end{array}$ \\
\hline \multirow[t]{2}{*}{$\begin{array}{l}\text { Sacral nerve } \\
\text { roots }\end{array}$} & $\begin{array}{l}\text { Constipation/ } \\
\text { irritable bowel/fecal } \\
\text { incontinence }\end{array}$ & & $\begin{array}{l}\text { - } 88 \% \text { bloating } \\
\text { - } 56 \% \text { constipation } \\
\text { - } 35 \% \text { diarrhea } \\
\text { - } 56 \% \text { incontinence }{ }^{2} \\
\end{array}$ & $38 \%$ irritable bowel ${ }^{45}$ \\
\hline & $\begin{array}{l}\text { Bladder retention/ } \\
\text { irritable bladder/urinary } \\
\text { incontinence }\end{array}$ & $30 \%$ nocturia ${ }^{101}$ & $\begin{array}{l}\text { - Urodynamic testing: mostly } \\
\text { detrusor overactivity } \\
\text { - } 39 \% \text { irritable or painful } \\
\text { bladder }{ }^{46} \\
\end{array}$ & $\begin{array}{l}39.8 \% \text { urinary incontinence } \\
\text { or increased frequency }{ }^{45}\end{array}$ \\
\hline $\begin{array}{l}\text { Sympathetic } \\
\text { overactivity }\end{array}$ & Sympathetic overactivity & $\begin{array}{l}\text { Intracranial pressure is a } \\
\text { determinant of sympathetic } \\
\text { activity }{ }^{92}\end{array}$ & $\begin{array}{l}60 \% \text { of studies describe } \\
\text { sympathetic activity } \\
\text { predominance }^{62}\end{array}$ & $\begin{array}{l}60 \% \text { of studies describe } \\
\text { sympathetic activity } \\
\text { predominance }^{62}\end{array}$ \\
\hline \multirow[t]{7}{*}{ Miscellaneous } & Female predominance & $90 \%$ women 11 & $\begin{array}{l}1990 \text { diagnostic criteria: } 90 \% \\
\text { women }^{20}\end{array}$ & $90.9 \%$ women $^{30}$ \\
\hline & Inheritance & $\begin{array}{l}5 \%-40 \% \text { family members } \\
\text { with } \mathrm{ICH}^{50,101}\end{array}$ & Strong familial aggregation ${ }^{13}$ & $\begin{array}{l}\text { Significant relative risk } \\
\text { among first-, second-, and } \\
\text { third-degree relatives' }\end{array}$ \\
\hline & Associated with EDS & $\begin{array}{l}\text { Anecdotal reports of large } \\
\text { case series suggest an } \\
\text { association }^{40}\end{array}$ & $\begin{array}{l}\text { 9\% of EDS patients are diagnosed } \\
\text { with } \mathrm{FM}^{85}\end{array}$ & $\begin{array}{l}\text { Fatigue is common and } \\
\text { often disabling in } \operatorname{EDS}^{39}\end{array}$ \\
\hline & Obesity & $88 \%$ obese $^{101}$ & $\begin{array}{l}34 \% \text { of morbidly obese } \\
\text { individuals have } \mathrm{FM}^{26}\end{array}$ & $\begin{array}{l}\text { Increased prevalence of } \\
\text { obesity }{ }^{70}\end{array}$ \\
\hline & $\begin{array}{l}\text { Depression/anxiety/ } \\
\text { quality of life }\end{array}$ & $\begin{array}{l}13 \% \text { depression, } 16 \% \\
\text { anxiety }^{54}\end{array}$ & $\begin{array}{l}66 \% \text { moderate-to-severe } \\
\text { depression }\end{array}$ & $11 \%$ depression ${ }^{13}$ \\
\hline & Sleep disturbances & $82 \%^{54}$ & $50 \% 55$ & $92 \%^{13}$ \\
\hline & Disability & $\begin{array}{l}31 \% \text { of individuals change } \\
\text { occupation due to } \mathrm{ICH}^{34}\end{array}$ & $31 \%$ disability 32 & $\begin{array}{l}27 \%-41 \% \text { unemployment } \\
\text { rates }^{65}\end{array}$ \\
\hline
\end{tabular}

Notes: The percentages represent the proportion of patients displaying that sign or symptom, unless indicated otherwise.

Abbreviations: CFS, chronic fatigue syndrome; CSP, cerebrospinal pressure; EDS, Ehlers-Danlos syndrome; FM, fibromyalgia; IICH, idiopathic intracranial hypertension.

These cognitive impairments may be associated with premature gray matter loss, as seen in patients with FM and CFS. Patients with FM may have a greater overall $l^{57}$ or regional ${ }^{83}$ premature age-associated gray matter volume loss. Similar regional gray matter changes were found in MRI studies of patients with CFS. Several other chronic pain disorders have been associated with gray matter reductions such as vulvodynia, irritable bowel syndrome, tension headache, and chronic back pain. ${ }^{76,84}$ It is not clear whether these gray matter changes are the cause or the consequence of FM or CFS. However, this hypothesis proposes that these changes might be related to damage to neurons due to mechanical compression from elevated ICP.

\section{Cranial nerve involvement}

It has been shown that the perineural spaces of several cranial nerves including the olfactory, optic, trigeminal, and auditory nerves show multiple lymphatic pathways of CSF drainage toward the retropharyngeal and cervical lymph nodes. ${ }^{19}$

When CSP increases, CSF is forced into the cranial nerve root sheaths. This might compromise the blood supply or cause mechanical pressure on the neurons or axons during their intracranial course.

\section{The olfactory nerve (I)}

Patients with IICH often show decreased olfactory bulb volumes ${ }^{91}$ and impaired olfactory function. ${ }^{9}$ These findings 


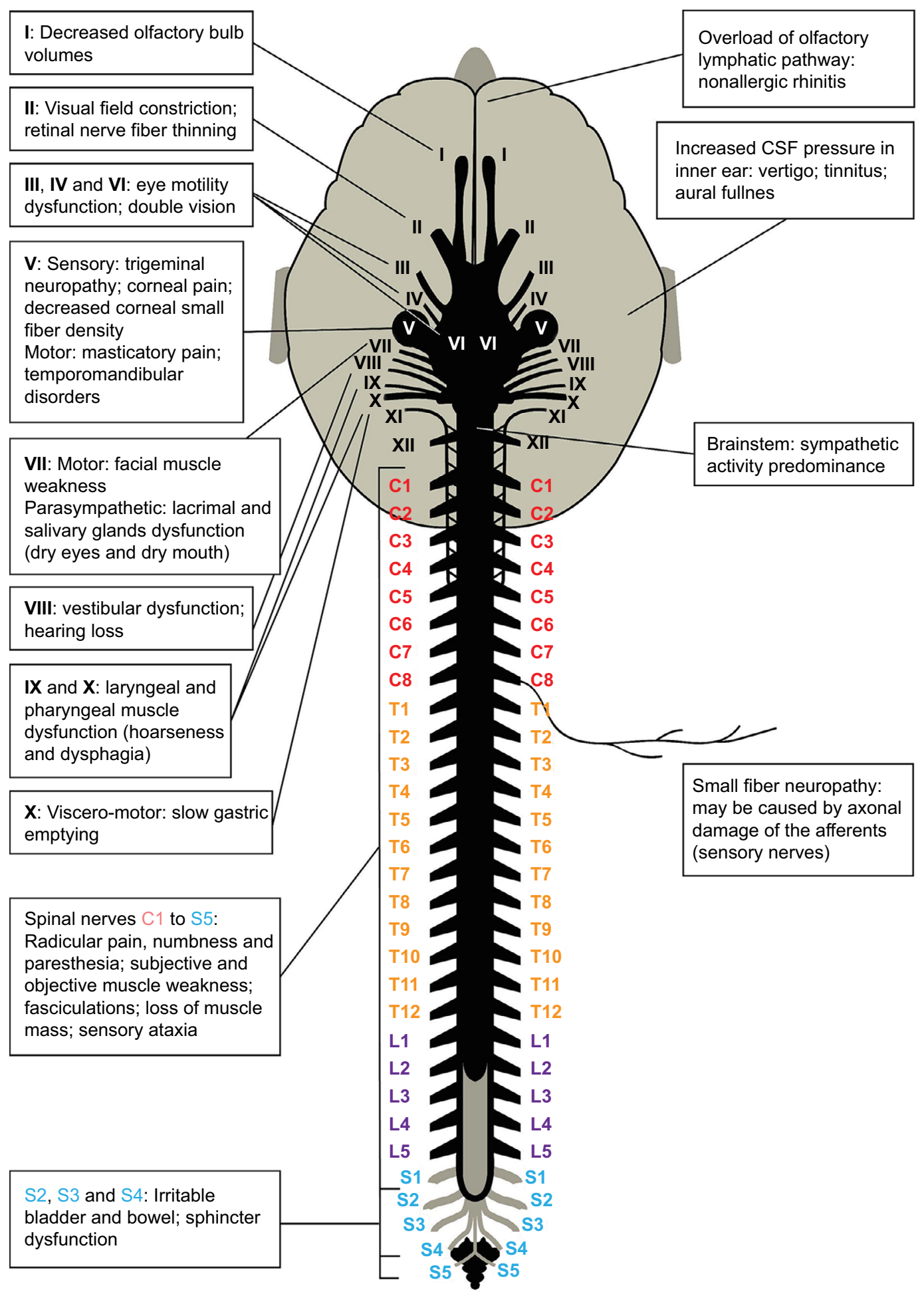

Figure I Overview of the interactions of ICP with all the nerves presented in this paper, the olfactory lymphatic pathway, and the inner ear. Abbreviations: CSF, cerebrospinal fluid; ICP, intracranial pressure.

have also been reported for patients with FM. ${ }^{3}$ It is most likely that these symptoms are due to increased pressure compromising the blood supply and damaging the olfactory nerve cell bodies.

\section{The optic nerve (II)}

In $\mathrm{IICH}$, the optic nerve diameter may be increased as the pressure of the CSF dilates the nerve sheath. ${ }^{96}$ Additionally, due to the increased pressure, the optic nerve fibers inside 
may be damaged. Consequently, even in the absence of papilledema, peripheral visual field defects may occur. ${ }^{27}$

Visual field defects have been detected in patients with $\mathrm{FM},{ }^{75,102}$ which might indicate that the nerve root fibers of the optic nerve are damaged by the increased pressure.

Figure 2 shows T2-weighted sagittal MRI images of a dilated optic nerve in a 46-year-old female patient with unexplained widespread pain. She was later diagnosed with IICH because a lumbar puncture revealed an OP of $23 \mathrm{~cm}$ $\mathrm{H}_{2} \mathrm{O}$, and visual field defects were detected. Evacuation of $20 \mathrm{~mL}$ of CSF dramatically improved her symptoms during a period of 2 or 3 days.

The oculomotor nerve (III), trochlear nerve (IV), and abducens nerve (VI)

The third, fourth, and sixth cranial nerves control the motor function of the eye muscles. In IICH, compression of these nerves may cause oculomotor weakness, and patients present with double vision and, in severe cases, even oculomotor palsy. ${ }^{59,101}$ In patients with FM and CFS, double vision has been reported, and in patients with CFS, eye motility dysfunction has been observed. ${ }^{6,37,87,102}$

\section{The trigeminal nerve $(\mathrm{V})$}

The motor fibers of the fifth cranial nerve supply the masticatory muscles. Irritation of these fibers may produce hypertonia of the masticatory muscles, bruxism, temporomandibular disorders, and masticatory pain. The sensory

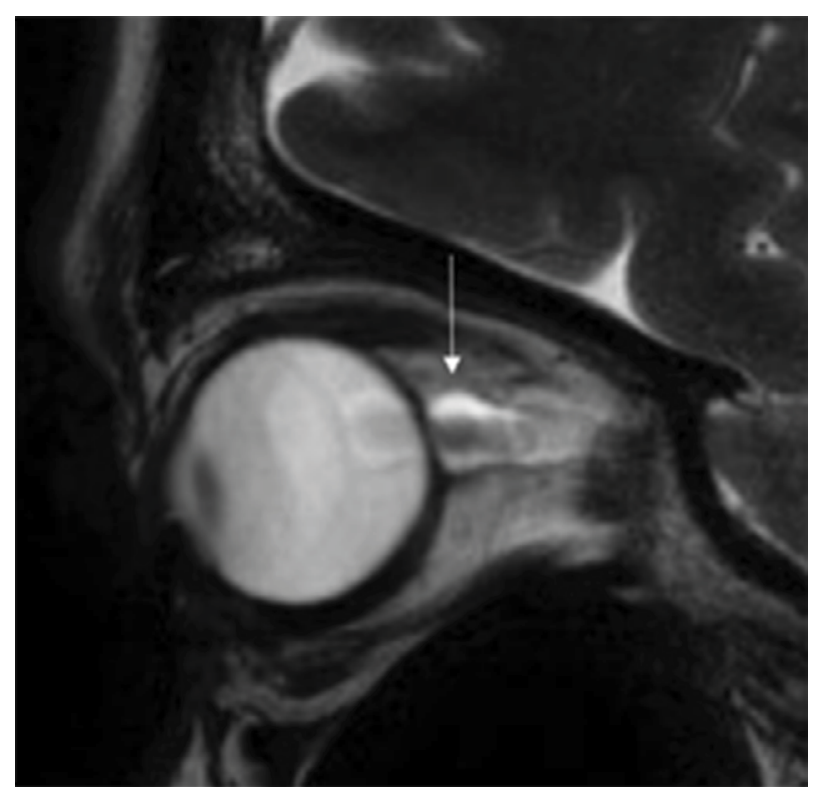

Figure 2 Dilated optic nerve of a patient with visual field defects and unexplained widespread pain. fibers supply the facial dermatomes. Irritation of these fibers may produce facial pain. In patients with IICH, there have been reports of trigeminal hypersensitivity or neuralgia of the trigeminal dermatome. Electrophysiologic studies have indicated trigeminal nerve involvement, and the symptoms were reversed following lumbar puncture. ${ }^{4}$

Hypertonia of the masticatory muscles and facial pain are commonly reported in patients with FM and CFS. ${ }^{68,83}$

Additionally, small fiber scarcity has been detected in women suffering from FM by measuring corneal nerve fiber thickness with a confocal microscope. In these patients, nerve scarcity was associated with neuropathic pain descriptors. ${ }^{77}$ Small fiber neuropathy in the cornea may be the consequence of damage to the sensory afferents in the trigeminal nerves.

\section{The facial nerve (VII)}

The motor fibers of the facial nerve innervate the muscles of the face. In IICH, several cases of facial weakness or facial palsy due to nerve fiber compression have been reported. ${ }^{101}$ The facial nerve supplies the autonomic function of the salivary and the lacrimal glands. A few cases of Sicca syndrome ${ }^{94}$ were reported in patients with IICH. According to this hypothesis, this may be due to the compression of the autonomic fibers running toward the salivary and lacrimal glands.

To the best of our knowledge, facial nerve weakness has not been reported in patients with FM or in CFS. However, in patients with FM and those with CSF, the symptoms of dry eyes and dry mouth are highly prevalent. ${ }^{18,89}$

Additionally, in cases of severe dry eyes, the sensory trigeminal nerve fibers supplying the conjunctiva and the cornea may also be involved. Severe dry eye is a condition that is shared by patients with FM and those with CFS. It has been suggested that severe dry eyes are the consequence of a corneal somatosensory dysfunction, and evidence suggests that in some patients, the symptom of severe dry eyes may actually be neuropathic ocular pain. ${ }^{58}$

\section{The vestibulocochlear nerve (VIII)}

The eighth cranial nerve provides the sensory innervation of the inner ear, that is, the cochlea for hearing and the vestibula for balance. Irritation or damage to the nerve fibers may cause hearing loss or vertigo in patients with IICH.

Hearing loss and vertigo may also result from the transmission of increased CSF pressure to the inner ear via the cochlear aqueduct. Menière's disease and IICH share similar symptoms, such as a higher prevalence of vertigo, tinnitus, aural fullness, sensorineural hearing loss, and headache. 
When lumbar puncture was performed in patients with IICH, vertigo, dizziness, fluctuating hearing loss, tinnitus, and aural fullness improved. ${ }^{78}$ Additionally, the medical management strategies are similar for both IICH and Menière's disease, for example, diuretics and corticosteroids. ${ }^{21,95}$

Patients with FM often complain of subjective hearing loss. Recently, objective audiologic abnormalities were detected in patients with FM. ${ }^{49,102}$

Additionally, vestibular test abnormalities were detected in patients with CFS. 5,73

The glossopharyngeal nerve (IX) and the vagus nerve (X)

The ninth and tenth cranial nerves supply the sensory and motor functions of the larynx and the pharynx. The hoarseness and dysphagia reported in patients with FM and those with CFS are probably caused by the compression of the ninth and tenth cranial nerve motor fibers. ${ }^{81,102}$

The tenth cranial nerve supplies the parasympathetic innervation of the cardiovascular, respiratory, and gastrointestinal systems. This might explain why increased ICP is associated with slower gastric emptying, as seen in brain-injured patients. ${ }^{66}$ In patients with FM and those with CFS, slower gastric emptying is a common complaint, ${ }^{74}$ and in patients with CFS, slower gastric emptying has been observed. ${ }^{12}$

\section{The olfactory lymphatic pathway}

As previously mentioned, CSF drainage routes involve the flow of CSF along the perineural space of the cranial nerves. The most common pathway involves the olfactory nerve, the fibers of which leave the olfactory bulb and penetrate through the foramina of the cribriform plate to leave the brain. The endothelial layer of the olfactory nerve sheath becomes thinner in the nasal mucosa covering the conchae, nasal septum, ethmoid sinus, and lateral walls of the nasal cavity. Subsequently, CSF penetrates through the endothelium into the lymphatic pathways of the nasal submucosa toward the regional lymph nodes..$^{19,48}$

In patients with IICH, several cases of sinusitis have been reported. Masri reported that 5 (26\%) of 19 children with IICH had sinusitis. ${ }^{36,52,63,64}$

In patients with severely increased CSP, a spontaneous dural leak through the thin layer of the olfactory nerve root sheath may cause rhinorrhea. ${ }^{60}$

In patients with FM and those with CFS, idiopathic nonallergic rhinitis is a common symptom and presents as nasal obstruction and rhinorrhea. ${ }^{8}$ According to this hypothesis, obstruction of the nose and rhinorrhea may occur when the olfactory lymphatic drainage system becomes saturated by excess CSF. Excess CSF might cause swelling of the nasal submucosa and leaking of CSF into the paranasal and nasal cavities may cause rhinorrhea or sinusitis. In addition, when CSF pressure is severely increased, a spontaneous transnasal dural leak may occur.

\section{Symptoms associated with increased spinal pressure}

\section{The spinal nerves}

As the ICP increases, when the patient is in the upright position, due to hydrostatic pressure, the CSF will be forced downwards into the spinal subarachnoid space and, subsequently into the subarachnoid space of the nerve root sheaths.

Sacral nerve root sheath dilations can be observed, which appear very similar to the optic nerve root sheath dilations. Figure 3A shows T2-weighted sagittal MRI images of such nerve root dilations in the sacrum of the patient that was initially diagnosed with FM and CFS shown in Figure 2. Figure 3B shows a more lateral view of the sacrum, demonstrating a significant dilation or Tarlov cyst on nerve root S3.

As the pressure inside the nerve root sheath increases, the nerve root fibers inside may be irritated or compressed, and radicular pain may occur. As mentioned above, radicular pain in IICH is a common but underestimated symptom. ${ }^{101}$ Irritation or compression of the nerve fibers in the spinal nerves may also produce numbness, paresthesia, or weakness in the arms and legs. ${ }^{33}$ Similar symptoms have been detected in FM and CFS patients. ${ }^{17,55}$ More than half of the patients with FM complain of weakness in the arms and legs, and in $13 \%$ of patients with FM, the weakness is associated with the loss of muscle mass. ${ }^{102}$ Electromyography and nerve conduction studies have objectified demyelinating and/or axonal sensorimotor polyneuropathy in $90 \%$ of FM patients. ${ }^{15}$

Additionally, different authors have reported small fiber neuropathy detected in skin biopsies of patients with FM. ${ }^{29}$ It has been speculated that small fiber neuropathy may be the consequence of immunologic processes. However, small fiber neuropathy may also be the consequence of axonal damage of the central afferents of the small fibers, that is, sensory nerves.

When performing a lumbar puncture in patients with chronic unexplained pain or FM, $50 \%$ of patients showed an OP at or above $20 \mathrm{~cm} \mathrm{H}_{2} \mathrm{O}$. Following the evacuation of 15-25 mL of CSF, $70 \%$ of patients responded with significant improvement of their pain symptoms. ${ }^{44}$

Patients with IICH may present with walking difficulties, mostly ataxia. ${ }^{33}$ It is likely that radiculopathy may cause 

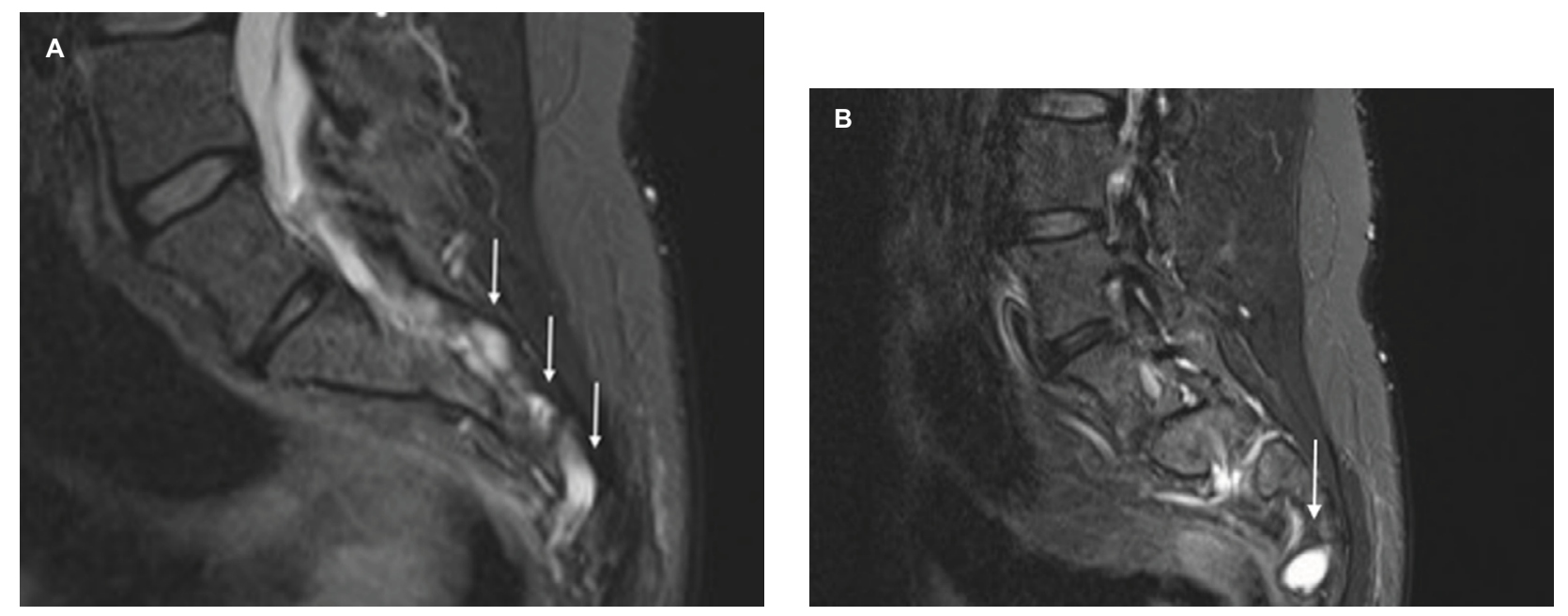

Figure 3 (A) Sacral nerve root sheath dilations can be observed, and these appear to be very similar to the optic nerve root sheath dilations. (B) A more lateral view of the sacrum showing significant dilation (Tarlov cyst) of nerve root S3.

sensory ataxia due to damage to the afferent fibers carrying the proprioceptive information from the legs. Ataxia and poor balance in patients with FM and reduced gait automaticity in patients with CFS have been reported. ${ }^{28,102}$

In humans in the upright position, the hydrostatic pressure is higher inside the sacral nerve roots than in the lumbar, dorsal, and cervical nerve roots. Therefore, if the CSP increases, the sacral nerve roots are at the greatest risk. The sacral nerve roots provide the autonomic innervation of the distal colon and the detrusor of the bladder as well as the motor innervation of the anal and urinary sphincters. This may explain why urinary incontinence and nocturia may occur in patients with IICH. ${ }^{101}$

In patients with FM and those with CFS, bladder, bowel, and sphincter dysfunctions are commonly reported. Urodynamic testing in patients with FM showed that detrusor overactivity was the most common observation. ${ }^{23}$

\section{Sympathetic activity predominance}

The sympathetic nervous system prepares the body to fight or flight. Sympathetic activity predominance symptoms include the following: digestive problems (slower gastric emptying), constipation (slower bowel peristalsis), superficial breathing, tachycardia, postural hypotension, anxiety, night sweats, poor sleep quality, obstructive sleep apnea, and fatigue.

Use of muscle microneurography to assess sympathetic activity showed that a $9 \mathrm{~cm} \mathrm{H}_{2} \mathrm{O}$ ICP increase (from 11 to 20 $\mathrm{cm} \mathrm{H}_{2} \mathrm{O}$ ) significantly increased sympathetic activity by $17 \%$. This was probably due to pressure sensitive receptors in the brainstem that have the potential to trigger a sympathetically mediated systemic response..$^{92}$

A systematic review revealed that $60 \%$ of studies on FM and CFS describe sympathetic activity predominance in those conditions. The most frequently used methods to assess sympathetic functionality were heart rate variability analysis, tilt table testing, sympathetic skin response, and genetic studies. ${ }^{62}$

\section{Miscellaneous}

\section{Genetic origin}

Patients suffering from IICH, FM, and CFS are significantly predominantly female ${ }^{11,20,30,101}$ and there is a strong indication of family inheritance. ${ }^{1,13,50}$ Additionally, patients with connective tissue disorders, such as Ehlers-Danlos syndrome, have increased risk of developing one of these three conditions. ${ }^{39,40,85}$ This may indicate that genetic defects may play a role in ICP dysregulation.

\section{Obesity}

IICH is mostly diagnosed in obese female patients. Obesity increases intra-abdominal pressure and therefore also increases ICP. ${ }^{101}$ This hypothesis might explain why obese women have an increased risk of developing FM or CFS. ${ }^{26,70}$

\section{Depression/anxiety/poor quality of life}

It is well known that FM and CFS patients suffer from depression, anxiety, and poor quality of life. ${ }^{20,47}$ 
IICH is also characterized by poor quality of life and headaches or obesity alone cannot account for this result. ${ }^{54}$

\section{Sleep disturbances}

Among FM patients, 70\% were found to suffer from sleep disorders. ${ }^{55}$ Sleep disturbances are associated with the symptoms of sympathetic overactivity, such as a higher heart rate during sleep in patients with FM compared to healthy controls. In patients with FM, sleep is less efficient than in healthy controls, with a higher proportion of non-rapid eye movement sleep, more arousals, more periodic limb movements, and a higher proportion of periodic breathing (cyclic abnormalities in the breathing pattern including episodes of apnea and hypopnea). ${ }^{82}$

Among adolescent patients with CFS, $69 \%$ were found to suffer from one or more sleep disorders such as obstructive sleep apnea (40\%), periodic limb movement disorder (9\%), and restless legs syndrome (41\%). ${ }^{47}$

Similarly, $82 \%$ of patients with IICH may suffer from sleep disturbances. ${ }^{54}$

\section{Disability}

Additionally, as in patients with FM and those with CFS, patients with IICH have a high rate of disability, as reflected by objective measures such as unemployment. ${ }^{32,65}$ Patients with IICH also have a high hospital admission rate $(38 \%$ in 2007), which is only partly due to the higher rate of concomitant obesity. ${ }^{34}$

\section{The role of cerebral blood flow in the pathophysiology of IICH, FM, and CFS}

Although the pathophysiology of IICH is unknown, growing evidence suggests that cerebral venous outflow obstruction due to transverse sinus stenosis may be the underlying cause. Bilateral transverse sinus stenosis can be identified on magnetic resonance venography in more than $90 \%$ of patients with IICH and only in 3\% of healthy controls. ${ }^{69}$

Venous sinus stenting was applied as a management strategy in patients with IICH with and without papilledema, resolving the condition in all papilledema patients and improving overall symptoms by $89 \%{ }^{14}$ Venous sinus stenting has been used for the treatment of a CFS patient with borderline IICH, after which pressure headache, fatigue, concentration, and pain significantly improved and she was able to return to work. ${ }^{42}$

Arterial cerebral blood flow may also play a role. In FM patients, cerebral blood flow velocity characteristics assessed by transcranial Doppler showed significant differences compared with healthy controls ${ }^{86} \mathrm{CFS}$ patients often present with orthostatic intolerance symptoms, such as blurred vision, dizziness, lightheadedness, sweating, and/or headaches that occur when a patient changes from a supine to an upright position. In these patients, cerebral blood flow autoregulation efficiency is likely reduced. Using quantitative flow MRI techniques, it was demonstrated that CFS patients with more severe orthostatic intolerance symptoms exhibited higher levels of cerebral perfusion and lower levels of intracranial compliance. Cerebral compliance represents the ability to buffer increased intracranial volume while preventing rise of the ICP. ${ }^{31}$

\section{Conclusion}

IICH, FM, and CFS share very similar characteristics and are probably caused by the same underlying disorder of increased CSP. IICH, FM, and CFS can be considered progressive neurologic disorders affecting the central and peripheral nervous systems.

This hypothesis may also provide an explanation for several overlapping chronic pain conditions. These include FM, CFS, temporomandibular disorders, irritable bowel syndrome, chronic tension headache, chronic migraine, severe dry eyes, and chronic nonspecific low back pain.

Unraveling the physiopathology of FM and CFS is important for the recognition of the suffering of patients with these disorders, as there is a stigma associated with the diagnosis of FM or CFS. Moreover, future research should probably focus on therapeutic strategies to lower CSF pressure.

\section{Disclosure}

The authors report no conflicts of interest in this work.

\section{References}

1. Albright F, Light K, Light A, Bateman L, Cannon-Albright LA. Evidence for a heritable predisposition to Chronic Fatigue Syndrome. BMC Neurol. 2011;11(1):62.

2. Almansa C, Rey E, Sánchez RG, Sánchez AA, Díaz-Rubio M. Prevalence of functional gastrointestinal disorders in patients with fibromyalgia and the role of psychologic distress. Clin Gastroenterol Hepatol. 2009;7(4):438-445.

3. Amital H, Agmon-Levin N, Shoenfeld N, et al. Olfactory impairment in patients with the fibromyalgia syndrome and systemic sclerosis. Immunol Res. 2014;60(2-3):201-207.

4. Arsava EM, Uluc K, Nurlu G, Kansu T. Electrophysiological evidence of trigeminal neuropathy in pseudotumor cerebri. J Neurol. 2002;249(11):1601-1602.

5. Ash-Bernal R, Wall C, Komaroff AL, et al. Vestibular function test anomalies in patients with chronic fatigue syndrome. Acta Otolaryngol. 1995;115(1):9-17.

6. Badham SP, Hutchinson CV. Characterising eye movement dysfunction in myalgic encephalomyelitis/chronic fatigue syndrome. Graefes Arch Clin Exp Ophthalmol. 2013;251(12):2769-2776. 
7. Baraniuk JN, Clauw D, Yuta A, et al. Nasal secretion analysis in allergic rhinitis, cystic fibrosis, and nonallergic fibromyalgia/chronic fatigue syndrome subjects. Am J Rhinol. 1998;12(6):435-440.

8. Baraniuk JN, Zheng Y. Relationships among rhinitis, fibromyalgia, and chronic fatigue. Allergy Asthma Proc. 2010;31(3):169-178.

9. Bershad EM, Urfy MZ, Calvillo E, et al. Marked olfactory impairment in idiopathic intracranial hypertension. J Neurol Neurosurg Psychiatry. 2014;85(9):959-964.

10. Bortoluzzi M, Di Lauro L, Marini G. Benign intracranial hypertension with spinal and radicular pain. Case report. J Neurosurg. 1982;57(6):833-836.

11. Bruce BB, Kedar S, Van Stavern GP, et al. Idiopathic intracranial hypertension in men. Neurology. 2009;72(4):304-309.

12. Burnet RB, Chatterton BE. Gastric emptying is slow in chronic fatigue syndrome. BMC Gastroenterol. 2004;4(1):32.

13. Buskila D, Sarzi-Puttini P, Ablin JN. The genetics of fibromyalgia syndrome. Pharmacogenomics. 2007;8(1):67-74.

14. Cappuzzo JM, Hess RM, Morrison JF, et al. Transverse venous stenting for the treatment of idiopathic intracranial hypertension, or pseudotumor cerebri. Neurosurg Focus. 2018;45(1):E11.

15. Caro XJ, Galbraith RG, Winter EF. Evidence of peripheral large nerve involvement in fibromyalgia: a retrospective review of EMG and nerve conduction findings in 55 FM subjects. Eur J Rheumatol. 2018;5(2):104-110.

16. Caro XJ, Winter EF, Dumas AJ. A subset of fibromyalgia patients have findings suggestive of chronic inflammatory demyelinating polyneuropathy and appear to respond to IVIg. Rheumatology. 2008;47(2):208-211.

17. Carruthers BM, van de Sande MI, de Meirleir KL, et al. Myalgic encephalomyelitis: International Consensus Criteria. J Intern Med. 2011;270(4):327-338.

18. Chen CH, Yang TY, Lin CL, et al. Dry eye syndrome risks in patients with fibromyalgia: a national retrospective cohort study. Medicine. 2016;95(4):e2607.

19. Chen L, Elias G, Yostos MP, Stimec B, Fasel J, Murphy K. Pathways of cerebrospinal fluid outflow: a deeper understanding of resorption. Neuroradiology. 2015;57(2):139-147.

20. Clauw DJ. Fibromyalgia: a clinical review. JAMA. 2014;311(15): 1547-1555.

21. Çoban K, Aydın E, Özlüoğlu LN. Audio-vestibular findings in increased intracranial hypertension syndrome. J Int Adv Otol. 2017;13(1): 100-104.

22. Cvejic E, Birch RC, Vollmer-Conna U. Cognitive dysfunction in chronic fatigue syndrome: a review of recent evidence. Curr Rheumatol Rep. 2016;18(5):24.

23. de Araújo MP, Faria AC, Takano CC, et al. Urodynamic study and quality of life in patients with fibromyalgia and lower urinary tract symptoms. Int Urogynecol J Pelvic Floor Dysfunct. 2008;19(8): 1103-1107.

24. De Becker P, McGregor N, De Meirleir K. A definition-based analysis of symptoms in a large cohort of patients with chronic fatigue syndrome. J Intern Med. 2001;250(3):234-240.

25. De Simone R, Ranieri A, Montella S, et al. Intracranial pressure in unresponsive chronic migraine. J Neurol. 2014;261(7):1365-1373.

26. Dias DNG, Marques MAA, Bettini SC, Paiva EDS. Prevalence of fibromyalgia in patients treated at the bariatric surgery outpatient clinic of Hospital de Clínicas do Paraná - Curitiba. Rev Bras Reumatol Engl Ed. 2017;57(5):425-430.

27. Digre KB, Nakamoto BK, Warner JE, Langeberg WJ, Baggaley SK, Katz BJ. A comparison of idiopathic intracranial hypertension with and without papilledema. Headache. 2009;49(2):185-193.

28. Eyskens JB, Nijs J, Wouters K, Moorkens G. Reduced gait automaticity in female patients with chronic fatigue syndrome: Case-control study. J Rehabil Res Dev. 2015;52(7):805-814.

29. Farhad K, Oaklander AL. Fibromyalgia and small-fiber polyneuropathy: what's in a name? Muscle Nerve. 2018;131(4):611-613.
30. Faro M, Sàez-Francás N, Castro-Marrero J, Aliste L, Fernández de Sevilla T, Alegre J. Gender differences in chronic fatigue syndrome. Reumatol Clin. 2016;12(2):72-77.

31. Finkelmeyer A, He J, Maclachlan L, Blamire AM, Newton JL. Intracranial compliance is associated with symptoms of orthostatic intolerance in chronic fatigue syndrome. PLoS One. 2018;13(7):e0200068.

32. Fitzcharles MA, Ste-Marie PA, Rampakakis E, Sampalis JS, Shir Y. Disability in fibromyalgia associates with symptom severity and occupation characteristics. J Rheumatol. 2016;43(5):931-936.

33. Frič R, Eide PK. Comparative observational study on the clinical presentation, intracranial volume measurements, and intracranial pressure scores in patients with either Chiari malformation Type I or idiopathic intracranial hypertension. J Neurosurg. 2017;126(4):1312-1322.

34. Friesner D, Rosenman R, Lobb BM, Tanne E. Idiopathic intracranial hypertension in the USA: the role of obesity in establishing prevalence and healthcare costs. Obes Rev. 2011;12(5):e372-e380.

35. Garcia-Martin E, Garcia-Campayo J, Puebla-Guedea M, et al. Fibromyalgia is correlated with retinal nerve fiber layer thinning. PLoS One. 2016;11(9):e0161574.

36. García-Pérez A, Espino M, Barrio A, et al. Pseudotumor cerebri associated with maxillary sinusitis: clinico-pathological study. Rev Neurol. 2000;31(1):45-48

37. Godts D, Moorkens G, Mathysen DG. Binocular vision in chronic fatigue syndrome. Am Orthopt J. 2016;66(1):92-97.

38. Groves MD, Mccutcheon IE, Ginsberg LE, Kyritsis AP. Radicular pain can be a symptom of elevated intracranial pressure. Neurology. 1999;52(5):1093-1095.

39. Hakim A, De Wandele I, O'Callaghan C, Pocinki A, Rowe P. Chronic fatigue in Ehlers-Danlos syndrome-hypermobile type. Am JMed Genet C Semin Med Genet. 2017;175(1):175-180.

40. Henderson FC, Austin C, Benzel E, et al. Neurological and spinal manifestations of the Ehlers-Danlos syndromes. Am J Med Genet C Semin Med Genet. 2017;175(1):195-211.

41. Higgins JNP, Pickard JD, Lever AML. Chronic fatigue syndrome and idiopathic intracranial hypertension: different manifestations of the same disorder of intracranial pressure? Med Hypotheses. 2017;105:6-9.

42. Higgins N, Pickard J, Lever A. Borderline intracranial hypertension manifesting as chronic fatigue syndrome treated by venous sinus stenting. J Neurol Surg Rep. 2015;76(2):e244-e247.

43. Hulens M, Dankaerts W, Stalmans I, et al. Fibromyalgia and unexplained widespread pain: the idiopathic cerebrospinal pressure dysregulation hypothesis. Med Hypotheses. 2018;110:150-154.

44. Hulens M, Rasschaert R, Dankaerts W, Stalmans I, Vansant G, Bruyninckx F. Spinal fluid evacuation may provide temporary relief for patients with unexplained widespread pain and fibromyalgia. Med Hypotheses. 2018;118:55-58.

45. Johnston SC, Staines DR, Marshall-Gradisnik SM. Epidemiological characteristics of chronic fatigue syndrome/myalgic encephalomyelitis in Australian patients. Clin Epidemiol. 2016;8:97-107.

46. Jones KD, Maxwell C, Mist SD, King V, Denman MA, Gregory WT. Pelvic floor and urinary distress in women with fibromyalgia. Pain Manag Nurs. 2015;16(6):834-840.

47. Josev EK, Jackson ML, Bei B, et al. Sleep quality in adolescents with chronic fatigue syndrome/myalgic encephalomyelitis (CFS/ME). J Clin Sleep Med. 2017;13(9):1057-1066.

48. Kapoor KG, Katz SE, Grzybowski DM, Lubow M. Cerebrospinal fluid outflow: an evolving perspective. Brain Res Bull. 2008;77(6):327-334.

49. Kapusuz Gencer Z, Balbaloğlu Ö, Özkırıș M, Saydam L. Does fibromyalgia have an effect on hearing loss in women? Turk J Med Sci. 2017;47(6):1699-1702.

50. Karaman K, Gverović-Antunica A, Zuljan I, et al. Familial idiopathic intracranial hypertension. Croat Med J. 2003;44(4):480-484.

51. Karapetyan A, Manvelyan H. EHMTI-0116. Tension type primary headaches and fibromyalgia: strong correlations. J Headache Pain. 2014;15(S1):C42. 
52. Keren T, Lahat E. Pseudotumor cerebri as a presenting symptom of acute sinusitis in a child. Pediatr Neurol. 1998;19(2):153-154.

53. Kincaid $\mathrm{O}$, Rowin J. Intracranial hypertension causing polyradiculopathy and late or absent F-waves. J Neurol Neurosurg Psychiatry. 2006;77(12):1384-1386.

54. Kleinschmidt JJ, Digre KB, Hanover R. Idiopathic intracranial hypertension: relationship to depression, anxiety, and quality of life. Neurology. 2000;54(2):319-324.

55. Koroschetz J, Rehm SE, Gockel U, et al. Fibromyalgia and neuropathic pain-differences and similarities. A comparison of 3057 patients with diabetic painful neuropathy and fibromyalgia. BMC Neurol. 2011;11(1):55

56. Kravitz HM, Katz RS. Fibrofog and fibromyalgia: a narrative review and implications for clinical practice. Rheumatol Int. 2015;35(7): 1115-1125.

57. Kuchinad A, Schweinhardt P, Seminowicz DA, Wood PB, Chizh BA, Bushnell MC. Accelerated brain gray matter loss in fibromyalgia patients: premature aging of the brain? J Neurosci. 2007;27(15): 4004-4007.

58. Levitt AE, Galor A, Chowdhury AR, et al. Evidence that dry eye represents a chronic overlapping pain condition. Mol Pain. 2017;13:1744806917729306.

59. Mallery RM, Friedman DI, Liu GT. Headache and the pseudotumor cerebri syndrome. Curr Pain Headache Rep. 2014;18(9):446.

60. Martínez-Capoccioni G, Serramito-García R, Martín-Bailón M, García-Allut A, Martín-Martín C. Spontaneous cerebrospinal fluid leaks in the anterior skull base secondary to idiopathic intracranial hypertension. Eur Arch Otorhinolaryngol. 2017;274(5):2175-2181.

61. Martínez-Lavin M, López S, Medina M, Nava A. Use of the leeds assessment of neuropathic symptoms and signs questionnaire in patients with fibromyalgia. Semin Arthritis Rheum. 2003;32(6):407-411.

62. Martínez-Martínez LA, Mora T, Vargas A, Fuentes-Iniestra M, Martínez-Lavín M. Sympathetic nervous system dysfunction in fibromyalgia, chronic fatigue syndrome, irritable bowel syndrome, and interstitial cystitis: a review of case-control studies. J Clin Rheumatol. 2014;20(3):146-150.

63. Masri A, Jaafar A, Noman R, Gharaibeh A, Ababneh OH. Intracranial hypertension in children: etiologies, clinical features, and outcome. $J$ Child Neurol. 2015;30(12):1562-1568.

64. Matach G, Cartry G, Al Hussein H, Desrats L, Ghalayini A, di Nolfo M. Idiopathic intracranial hypertension and sphenoid sinusitis: is there any relationship? J Fr Ophtalmol. 2007;30:2S:318.

65. Maxmen A. The invisible disability. Nature. 2018;553:14-17.

66. Mcarthur CJ, Gin T, Mclaren IM, Critchley JA, Oh TE, Te O. Gastric emptying following brain injury: effects of choice of sedation and intracranial pressure. Intensive Care Med. 1995;21(7):573-576.

67. Moosa A, Joy MA, Kumar A. Extensive radiculopathy: another false localising sign in intracranial hypertension. J Neurol Neurosurg Psychiatry. 2004;75(7):1080-1081.

68. Moreno-Fernández AM, Jiménez-Castellanos E, Iglesias-Linares A, Bueso-Madrid D, Fernández-Rodríguez A, de Miguel M. Fibromyalgia syndrome and temporomandibular disorders with muscular pain. A review. Mod Rheumatol. 2017;27(2):210-216.

69. Morris PP, Black DF, Port J, Campeau N. Transverse sinus stenosis is the most sensitive MR imaging correlate of idiopathic intracranial hypertension. AJNR Am J Neuroradiol. 2017;38(3):471-477.

70. Norris T, Hawton K, Hamilton-Shield J, Crawley E. Obesity in adolescents with chronic fatigue syndrome: an observational study. Arch Dis Child. 2017;102(1):35-39.

71. Oaklander AL, Herzog ZD, Downs HM, Klein MM. Objective evidence that small-fiber polyneuropathy underlies some illnesses currently labeled as fibromyalgia. Pain. 2013;154(11):2310-2316.

72. Obeid T, Awada A, Mousali Y, Nusair M, Muhayawi S, Memish S. Extensive radiculopathy: a manifestation of intracranial hypertension. Eur J Neurol. 2000;7(5):549-553.

73. Palaniappan R, Sirimanna T. Peripheral vestibular dysfunction in chronic fatigue syndrome. Int $J$ Pediatr Otorhinolaryngol. 2002;64(1):69-72.
74. Pamuk ON, Umit H, Harmandar O. Increased frequency of gastrointestinal symptoms in patients with fibromyalgia and associated factors: a comparative study. J Rheumatol. 2009;36(8):1720-1724.

75. Pilar Bambo M, Garcia-Martin E, Gutierrez-Ruiz F, et al. Study of perfusion changes in the optic disc of patients with fibromyalgia syndrome using new colorimetric analysis software. J Fr Ophtalmol. 2015;38(7):580-587.

76. Puri BK, Jakeman PM, Agour M, et al. Regional grey and white matter volumetric changes in myalgic encephalomyelitis (chronic fatigue syndrome): a voxel-based morphometry 3 T MRI study. Br J Radiol. 2012;85(1015):e270-e273.

77. Ramírez M, Martínez-Martínez LA, Hernández-Quintela E, VelazcoCasapía J, Vargas A, Martínez-Lavín M. Small fiber neuropathy in women with fibromyalgia. An in vivo assessment using corneal confocal bio-microscopy. Semin Arthritis Rheum. 2015;45(2):214-219.

78. Ranieri A, Cavaliere M, Sicignano S, Falco P, Cautiero F, de Simone R. Endolymphatic hydrops in idiopathic intracranial hypertension: prevalence and clinical outcome after lumbar puncture. Preliminary data. Neurol Sci. 2017;38(Suppl 1):193-196.

79. Ravindran MK, Zheng Y, Timbol C, Merck SJ, Baraniuk JN. Migraine headaches in chronic fatigue syndrome (CFS): comparison of two prospective cross-sectional studies. BMC Neurol. 2011;11(1):30.

80. Rehm SE, Koroschetz J, Gockel U, et al. A cross-sectional survey of 3035 patients with fibromyalgia: subgroups of patients with typical comorbidities and sensory symptom profiles. Rheumatology. 2010;49(6):1146-1152.

81. Rhodus NL, Fricton J, Carlson P, Messner R. Oral symptoms associated with fibromyalgia syndrome. J Rheumatol. 2003;30(8):1841-1845.

82. Rizzi M, Radovanovic D, Santus P, et al. Influence of autonomic nervous system dysfunction in the genesis of sleep disorders in fibromyalgia patients. Clin Exp Rheumatol. 2017;35 Suppl 105(3):74-80.

83. Robinson LJ, Durham J, Newton JL. A systematic review of the comorbidity between temporomandibular disorders and chronic fatigue syndrome. J Oral Rehabil. 2016;43(4):306-316.

84. Robinson ME, Craggs JG, Price DD, Perlstein WM, Staud R. Gray matter volumes of pain-related brain areas are decreased in fibromyalgia syndrome. J Pain. 2011;12(4):436-443.

85. Rodgers KR, Gui J, Dinulos MB, Chou RC. Ehlers-Danlos syndrome hypermobility type is associated with rheumatic diseases. Sci Rep. 2017;7(1):39636.

86. Rodríguez A, Tembl J, Mesa-Gresa P, Muñoz MÁ, Montoya P, Rey B Altered cerebral blood flow velocity features in fibromyalgia patients in resting-state conditions. PLoS One. 2017;12(7):e0180253.

87. Rosenhall U, Johansson G, Orndahl G. Eye motility dysfunction in chronic primary fibromyalgia with dysesthesia. Scand J Rehabil Med. 1987;19(4):139-145.

88. Round R, Keane JR. The minor symptoms of increased intracranial pressure: 101 patients with benign intracranial hypertension. Neurology. 1988;38(9):1461-1464.

89. Ruiz E, Alegre J, García Quintana AM, Aliste L, Blázquez A, Fernández de Sevilla T. Chronic fatigue syndrome: study of a consecutive series of 824 cases assessed in two specialized units. Rev Clin Esp. 2011;211(8):385-390.

90. Sayıllı S, Çullu N. Decreased olfactory bulb volumes in patients with fibromyalgia syndrome. Clin Rheumatol. 2017;36(12):2821-2824.

91. Schmidt C, Wiener E, Hoffmann J, et al. Structural olfactory nerve changes in patients suffering from idiopathic intracranial hypertension. PLoS One. 2012;7(4):e35221.

92. Schmidt EA, Despas F, Pavy-Le Traon A, et al. Intracranial pressure is a determinant of sympathetic activity. Front Physiol. 2018;9:11.

93. Simms RW, Goldenberg DL. Symptoms mimicking neurologic disorders in fibromyalgia syndrome. J Rheumatol. 1988;15(8):1271-1273.

94. Stanescu D, Bodaghi B, Huong DL, et al. Pseudotumor cerebri associated with Sjögren's syndrome. Graefes Arch Clin Exp Ophthalmol. 2003;241(4):339-342.

95. Tawfik KO, Stevens SM, Mihal D, et al. Radiographic evidence of occult intracranial hypertension in patients with Ménière's disease. Otolaryngol Head Neck Surg. 2017;157(2):260-268. 
96. Tuncel SA, Yılmaz E, Çağlı B, Tekataş A, Çelik Y, Ünlü ME. Lumbar opening pressure and radiologic scoring in idiopathic intracranial hypertension: is there any correlation? Pol J Radiol. 2017;82:701-705.

97. Üçeyler N, Sommer C. Objective evidence that small-fiber polyneuropathy underlies some illnesses currently labeled as fibromyalgia. Pain. 2013;154(11):2569-2569.

98. Üçeyler N, Sommer C. Fibromyalgia syndrome: a disease of the small nerve fibers? Z Rheumatol. 2015;74(6):490-495.

99. Vij B, Whipple MO, Tepper SJ, Mohabbat AB, Stillman M, Vincent A. Frequency of migraine headaches in patients with fibromyalgia. Headache. 2015;55(6):860-865.

100. Wall M, Corbett JJ, Friedman DI, Liu G, Digre K. Revised diagnostic criteria for the pseudotumor cerebri syndrome in adults and children. Neurology. 2014;83(2):198-200.

101. Wall M, Kupersmith MJ, Kieburtz KD, et al. Nordic Idiopathic Intracranial Hypertension Study Group: The idiopathic intracranial hypertension treatment trial: clinical profile at baseline. JAMA Neurol. 2014;71:693-701.
102. Watson NF, Buchwald D, Goldberg J, Noonan C, Ellenbogen RG. Neurologic signs and symptoms in fibromyalgia. Arthritis Rheum. 2009;60(9):2839-2844.

103. Yri HM, Fagerlund B, Forchhammer HB, Jensen RH. Cognitive function in idiopathic intracranial hypertension: a prospective case-control study. BMJ Open. 2014;4(4):e004376.

104. Yri HM, Rönnbäck C, Wegener M, Hamann S, Jensen RH. The course of headache in idiopathic intracranial hypertension: a 12-month prospective follow-up study. Eur J Neurol. 2014;21(12):1458-1464.

105. Zur D, Naftaliev E, Kesler A. Evidence of multidomain mild cognitive impairment in idiopathic intracranial hypertension. $J$ Neuroophthalmol. 2015;35(1):26-30.

\section{Publish your work in this journal}

The Journal of Pain Research is an international, peer reviewed, open access, online journal that welcomes laboratory and clinical findings in the fields of pain research and the prevention and management of pain. Original research, reviews, symposium reports, hypothesis formation and commentaries are all considered for publication.

\section{Dovepress}

The manuscript management system is completely online and includes a very quick and fair peer-review system, which is all easy to use. Visit http://www.dovepress.com/testimonials.php to read real quotes from published authors. 